ISSN 1411 - 0067 Jurnal Ilmu-Ilmu Pertanian Indonesia. Volume 9, No. 2, 2007, Hlm. 183 - 190

\title{
VARIASI GENETIK, HERITABILITAS, TINDAK GEN DAN KEMAJUAN GENETIK KEDELAI (Glycine max Merrill) PADA ULTISOL
}

\section{GENETIC VARIATION, HERITABILITY, GENE ACTION AND GENETIC ADVANCE OF SOYBEAN ON ULTISOL}

\author{
Suprapto $^{1)}$, dan Narimah Md Kairudin ${ }^{2)}$ \\ ${ }^{1)}$ Fakultas Pertanian-Universitas Bengkulu Jl. Raya Kandang Limun, Bengkulu 38371 \\ ${ }^{2}$ Pusat Pengajian Sains Sekitaran dan Sumber Alam, Fakulti Sains dan Teknologi, \\ Universiti Kebangsaan Malaysia. 43600 UKM Bangi, Selangor Darul Ehsan, Malaysia \\ nda143@yahoo.com
}

\begin{abstract}
Information on genetic variation, heritability, gene action and genetic advance were important in the development of soybean varieties adapted on Ultisol. The objective of this experiment was to estimate genetic variation, hertability, gene action and genetic advance from the populaton used in breeding program. Six genotypes, i.e Dempo, Cikuray, Davros, Orba, Sindoro and Wilis were intercrossed using diallel Griffings' Method 2 Model 1 (1956). These six genotypes and $15 \mathrm{~F}_{1}$ hybrids were planted on Ultisol using randomized complete block design with three replications located in Medan Baru village, Bengkulu city in 1999. The results of this experiment revealed that all traits showed low to high genetic variation, high broadsense heritability, low to high narrowsense heritability and genetic advance. Date of flowering and root length were fully controlled by additive gene action, however harvest index was fully controlled by negative dominant gene action and epistasis. Other traits were controlled by positive and negative partially dominant, and positive overdominant genes.
\end{abstract}

Key words : genetic variation, heritability, gene cation, genetic advance

\begin{abstract}
ABSTRAK
Informasi mengenai variasi genetik, heritabilitas, tindak gen dan kemajuan genetik penting dalam pengembangan varietas kedelai yang adaptif pada Ultisol. Tujuan penelitian ini adalah untuk mengestimasi variasi genetik, heritabilitas, tindak gen dan kemajuan genetik dari populasi kedelai yang digunakan dalam program pemuliaan tanaman. Enam genotip kedelai, yaitu Dempo, Cikuray, Davros, Orba, Sindoro dan Wilis disilangkan secara dialel menggunakan Metode 2 Model 1 Griffing (1956). Enam genotip dan 15 hasil persilangannya ditanam pada Ultiosol di desa Medan baru, Kodia Bengkulu tahun 1999, menggunakan rancangan acak kelompok lengkap dengan tiga ulangan. Hasil penelitian ini menunjukkan bahwa sifat yang diteliti menunjukkan variasi genetik yang rendah hingga tinggi, heritabilitas dalam arti luas yang tinggi, heritabilitas dalam arti sempit dan kemajuan genetik yang rendah hingga tinggi. Sifat waktu berbunga dan panjang akar sepenuhnya dikendalikan oleh tindak gen aditif, sedangkan sifat indeks panen sepenuhnya dikendalikan oleh tindak gen dominan lengkap negatif dan epistasis. Sifat-sifat lain yang diteliti dikendalikan oleh gen dominan sebagian positif, dominan sebagian negatif dan overdominan positif.
\end{abstract}

Kata kunci : variasi genetik, heritabilitas, tindak gen, kemajuan genetik 


\section{PENDAHULUAN}

Kedelai merupakan tanaman pangan penting di Indonesia dan kebutuhannya selalu meningkat setiap tahun. Untuk memenuhi kebutuhan kedelai tersebut, Indonesia harus mengimpornya setiap tahun. Upaya untuk meningkatkan produktivitas kedelai pada Ultisol diantaranya dengan merakit varietas yang tahan terhadap kemasaman tanah dan ketersediaan air yang terbatas. Untuk merakit varietas unggul pada Ultisol perlu diketahui informasi genetik yang relevan dengan tujuan pemuliaan seperti variasi genetik, heritabilitas, tindak gen dan estimasi kemajuan genetik yang akan dicapai.

Populasi dasar dengan variasi genetik yang tinggi merupakan bahan pemuliaan yang penting untuk perakitan varietas unggul. Populasi dasar yang memiliki variasi genetik tinggi akan memberi kan respon yang baik terhadap seleksi karena variasi genetik yang tinggi akan memberikan peluang besar untuk mendapatkan kombinasi persilangan yang tepat dengan gabungan sifat-sifat yang baik.

Heritabilitas menentukan keberhasilan seleksi karena heritabilitas dapat memberikan petunjuk suatu sifat lebih dipengaruhi oleh faktor genetik atau faktor lingkungan. Nilai heritabilitas yang tinggi menunjukkan bahwa faktor genetik lebih berperanan dalam mengendalikan suatu sifat dibandingkan faktor lingkungan (Knight, 1979; Poehlman, 1979). Oleh karena variasi genetik dan heritabilitas suatu sifat tergantung pada faktor lingkungan, maka pengukuran variasi genetik bahan pemuliaan kedelai dan heritabilitas suatu sifat pada lingkungan tertentu seperti pada Ultisol sangat penting. Cahaner and Hillel (1980); Mak (1986); Falconer and Mackay (1996) mengatakan bahwa variasi genetik dan heritabilitas suatu sifat dipengaruhi oleh populasi dan faktor lingkungan. Oleh sebab itu, nilai heritabilitas adalah khusus untuk suatu populasi pada keadaan lingkungan tertentu (Dudley and Moll, 1969). Karuniawan et al. (1991) mengatakan bahwa nilai heritabilitas suatu sifat dipengaruhi oleh metode dan populasi yang digunakan.

Nilai heritabilitas suatu sifat tergantung pada tindak gen yang mengendalikan sifat tersebut (Jain, 1982). Jika heritabilitas dalam arti sempit suatu sifat bernilai tinggi, maka sifat tersebut dikendali kan oleh tindak gen aditif pada kadar yang tinggi. Sebaliknya jika heritabilitas dalam arti sempit bernilai rendah, maka sifat tersebut dikendalikan oleh tindak gen bukan aditif (dominan dan epistatis) pada kadar yang tinggi (Singh and Murty, 1982). Menurut Jain (1982) heritabilitas akan bermakna jika varians genetik didominasi oleh varians aditif karena pengaruh aditif setiap alel akan diwariskan dari tetua kepada progeninya (Crowder, 1981). Hayward (1990) mengatakan bahwa pengaruh aditif dapat diwariskan, sedangkan pengaruh bukan aditif tidak diwariskan.

Informasi mengenai variasi genetik dan heritabilitas berguna untuk menentukan kemajuan genetik yang diperoleh dari seleksi (Knight, 1979; Fehr, 1987; Borojevic, 1990). Seleksi pada kedelai akan menunjukkan kemajuan genetik yang tinggi jika sifat yang dilibatkan dalam seleksi mempunyai variasi genetik dan heritabilitas yang tinggi. Jika nilai heritabilitas tinggi, sebagian besar variasi fenotip disebabkan oleh variasi genetik, maka seleksi akan memperoleh kemajuan genetik. Seleksi terhadap sifat yang mempunyai nilai heritabilitas tinggi dapat dilakukan pada generasi awal, sedangkan sifat yang menunjukkan nilai heritabilitas rendah, seleksi dapat dilakukan pada generasi akhir (Zen, 1995). Sifat-sifat yang dikendalikan oleh gen-gen bukan aditif menyebabkan kemajuan genetik yang rendah. Hal ini disebabkan pengaruh tindak gen bukan aditif tidak diwariskan dan akan lenyap semasa seleksi (Hayward, 1990; Yap et al., 1990). Brewbaker (1964) mengatakan bahwa gen-gen dalam keadaan berangkai akan mengurangi kemajuan genetik. Oleh sebab itu kemajuan genetik melalui proses seleksi akan berlangsung secara cepat jika lokus bersegregasi secara bebas. Tujuan dari penelitian ini adalah untuk menentukan variasi 
genetik, heritabilitas, tindak gen dan kemajuan genetik kedelai pada Ultisol.

\section{METODE PENELITIAN}

Dua puluh satu genotip yang terdiri dari enam varietas unggul kedelai (Dempo, Cikuray, Davros, Orba, Sindoro, Wilis) dan 15 hasil persilangan dialel lengkap ditanam di Ultisol, desa Medan Baru, Kotamadia Bengkulu pada tahun 1999 mengguna kan Rancangan Acak Kelompok Lengkap tiga ulangan. Pada penelitian ini digunakan plot dengan ukuran $1.8 \times 1.0 \mathrm{~m}^{2}$ dengan jarak tanam $30 \mathrm{~cm} \mathrm{x}$ $20 \mathrm{~cm}$.

Sebelum ditanam, benih kedelai direndam dalam air selama dua menit kemudian dicampur dengan Superhizogen dengan kadar $3 \mathrm{~g} \mathrm{~kg}^{-1}$ benih. Benih dianam sebanyak satu buji per lubang. Tanaman kedelai dipupuk Urea, TSP dan $\mathrm{KCl}$ dengan dosis masing-masing 50, 100 dan $100 \mathrm{~kg}$ ha $^{-1}$. Pupuk diberikan dengan cara memasukkan nya ke dalam alur yang terletak di antara barisan tanaman dengan kedalaman lebih kurang $5 \mathrm{~cm}$. TSP dan $\mathrm{KCl}$ diaplikasikan pada saat tanam, sedangkan Urea diaplikasikan dua kali, yaitu separuh dosis diaplikasikan pada saat tanam dan separuh lagi diaplikasikan pada saat tanaman kedelai berumur 21 hari setelah tanam. Pengendalian hama menggunakan Decis 2.5 EC pada kadar $1 \mathrm{~mL} \mathrm{~L}^{-1}$ air, sedangkan pengendalian penyakit menggunakan Anvil 50 EC pada kadar 1 $\mathrm{mL} \mathrm{L} \mathrm{L}^{-1}$ air. Pengendalian hama dan penyakit dilakukan pada minggu ke-2, 4, 6 dan 8 setelah tanam. Pengendalian gulma dilakukan secara manual dengan mencabut gulma yang tumbuh.

Variasi genetik ditentukan berdasarkan pada koefisien variasi genetik (KVG) menggunakan metode yang dikemukakan oleh Singh and Chaudhari (1979) sebagai berikut :

$K V G=\left(\sigma_{\mathrm{g}} \overline{\mathrm{X}}\right) \times 100 \%$

di mana,

$\sigma_{\mathrm{g}}=$ akar varians genotip

$\overline{\mathrm{X}}=$ rata-rata nilai sifat

Nilai KVG mutlak yang tertinggi ditetapkan dari nilai KVG relatif $100 \%$.
Estimasi komponen genetik dapat dihitung sebagai berikut :

Varians genetik $\left(\hat{o}_{\mathrm{g}}^{2}\right)=\left(\mathrm{M}_{2}-\mathrm{M}_{3}\right) / \mathrm{r}$

Varians lingkungan $\left(\hat{o}_{\mathrm{e}}^{2}\right)=\mathrm{M}_{3}$

Varians fenotip $\left(\hat{o}_{\mathrm{f}}^{2}\right)=\hat{o}_{\mathrm{g}}^{2}+\hat{o}_{\mathrm{e}}^{2}$

di mana,

$\mathrm{M}_{2}=$ kuadrat tengah genotip pada analisis varians

$\mathrm{M}_{3}=$ kuadrat tengah galat pada analisis varians

$\mathrm{r} \quad=$ replikasi

Penentuan derajat dominansi bagi setiap persilangan berdasarkan pada nilai nisbah potensi (potence ratio) menggunakan formula yang dikemukakan oleh Petr dan Frey (1966 cit Rachmadi et al. 1990) sebagai berikut :

$\mathrm{hp}=\mathrm{F}_{1}$-MP/P-MP

di mana,

$\mathrm{hp}=$ nilai nisbah potensi

$\mathrm{P}=$ nilai tetua yang tertinggi

$\mathrm{F}_{1}=$ nilai hibrida $\mathrm{F}_{1}$

$\mathrm{MP}=$ nilai rata-rata dua tetua ( mid parent value) dengan kriteria :

$\mathrm{hp}=0$, tidak terdapat dominan (aditif)

$0<\mathrm{hp}<1$, dominan sebagian positif

$-1<\mathrm{hp}<0$, dominan sebagian negatif

$\mathrm{hp}=1$ atau $\mathrm{hp}=-1$, dominan lengkap positif atau dominan lengkap negatif

$\mathrm{hp}>1$ atau $\mathrm{hp}<-1$, overdominan positif atau overdominan negatif

Penentuan nilai heritabilitas dalam arti luas (broadsense heritability) menurut Fehr (1987) sebagai berikut :

$\mathrm{H}=\sigma_{\mathrm{g}}^{2} / \sigma_{\mathrm{f}}^{2}$

Kriteria heritabilitas menurut Haeruman et al. (1990), yaitu :

$\mathrm{Hd}$ d" $0,30 \quad=$ rendah

$0,30<\mathrm{H}$ d" $0,50=$ agak rendah

$0,50<\mathrm{H} \mathrm{d"} 0,70=$ agak tinggi

$\mathrm{H}>0,70 \quad=$ tinggi

Heritabilitas dalam arti sempit (narrowsense heritability) ditentukan dengan rumus berikut :

$$
\begin{aligned}
& \mathrm{h}=\frac{\mathrm{o}^{2}{ }_{\mathrm{A}}}{\mathrm{o}^{2}{ }_{\mathrm{A}}+\mathrm{o}^{2}{ }_{\mathrm{D}}+{\mathrm{o}^{2}}_{\mathrm{e}}} \\
& \text { Varians aditif }\left(\sigma^{2}{ }_{\mathrm{A}}\right)=4 \sigma^{2}{ }_{\mathrm{dgu}} \\
& \sigma_{\mathrm{dgu}}^{2}=\left(\mathrm{MS}_{\mathrm{dgu}}-\mathrm{MS}_{\mathrm{dgk}}\right) / \mathrm{b}(\mathrm{p}+2)
\end{aligned}
$$


Varians dominan $\left(\sigma_{\mathrm{D}}^{2}\right)=4 \sigma_{\mathrm{dgk}}^{2}$

$\sigma_{\text {dgk }}^{2}=\left(\mathrm{MS}_{\mathrm{dgk}}-\mathrm{MS}_{\mathrm{galat}}\right) / \mathrm{b}$

di mana,

$\mathrm{MS}_{\mathrm{dgu}}=$ kuadrat tengah dgu

$\mathrm{MS}_{\mathrm{dgk}}=$ kuadrat tengah dgk

$\mathrm{MS}_{\text {galat }}=$ kuadrat tengah galat

Kemajuan genetik (KG) dihitung berdasarkan metode yang dikemukakan oleh Singh and Chaudhari (1979).

$\mathrm{KG}=$ h.i. $\sigma_{\mathrm{f}}$

di mana,

$\mathrm{h}=$ heritabilitas dalam arti luas

$\mathrm{i}=$ intensitas seleksi dalam satuan baku. Pada intensitas seleksi $5 \%$ nilai $\mathrm{i}=2.06(\mathrm{Fehr}$, 1987)

$\sigma_{\mathrm{f}}=$ akar varians fenotip

dengan kriteria KG sebagai berikut :

$0.00-3.30 \%=$ rendah

$3.31-6.60 \%=$ agak rendah

$6.61-10.00 \%=$ agak tinggi

$>10 \%=$ tinggi

\section{HASIL DAN PEMBAHASAN}

Nilai koefisien variasi genetik (KVG) adalah 3.62-17.88\% (Tabel 1). Nilai KVG mutlak yang tertinggi ditetapkan dari nilai KVG relatif $100 \%$. Dalam penelitian ini dapat ditetapkan nilai KVG mutlak yaitu 0.00-4.470\% (rendah); 4.471-8.941\% (agak rendah); 8.942-13.413\% (agak tinggi) dan 13.414-17.880\% (tinggi).

Genotip-genotip (tetua dan progeni) menunjukkan nilai KVG rendah hingga agak rendah bagi sifat tinggi tanaman dan indeks panen masing-masing 7.94 dan $3.92 \%$. Hal ini bermakna bahwa genotip-genotip tersebut menunjukkan penampilan yang lebih kurang sama bagi kedua sifat tersebut. Kedua sifat tersebut menunjukkan nilai heritabilitas dalam arti luas agak tinggi hingga tinggi masing-masing 86 dan $67 \%$. Oleh sebab itu kedua sifat tersebut lebih banyak dikendalikan oleh faktor genetik dibandingkan dengan faktor lingkungan. Namun demikian, kedua sifat tersebut menunjukkan heritabilitas dalam arti sempit yang rendah hingga agak rendah masing - masing 48.31 dan $0.00 \%$. Hal ini menunjukkan bahwa sifat tinggi tanaman dikendalikan oleh tindak gen aditif dan bukan aditif pada kadar yang hampir sama. Hal ini dapat dipertegas dengan nilai sumbangan varians aditif terhadap varians genetik yang mencapai $51 \%$. Nilai nisbah potensi sebesar 0.71 menjelaskan bahwa gen dominan yang mengendalikan sifat tinggi tanaman adalah gen dominan sebagian positif. Nilai heritabilitas dalam arti sempit sifat indeks panen yang bernilai nol disebabkan oleh varians dgu dan varians aditif yang negatif. Hasil ini sesuai dengan analisis tindak gen sifat indeks panen yang sepenuhnya dikendalikan oleh tindak gen bukan aditif yang meliputi tindak gen dominan dan epistasis (aditif $\mathrm{x}$ dominan dan dominan $\mathrm{x}$ dominan).

Nilai nisbah potensi sebesar -1.00 menjelaskan bahwa gen dominan yang mengendali kan sifat indeks panen adalah gen dominan lengkap negatif. Dalam penelitiannya pada jagung manis, Sujiprihati et al. (2005) juga mendapati nilai nol pada varians genetik dan heritabilitas dalam arti luas untuk sifat diameter tongkol dan bobot tongkol. Nilai estimasi KG untuk sifat tinggi tanaman adalah $15.21 \%$ dengan kriteria tinggi. Hasil ini sesuai dengan pendapat Burton (1952) yang mengatakan bahwa jika kemajuan genetik suatu sifat bernilai tinggi tetapi nilai heritabilitas dalam arti sempit bernilai rendah, maka sifat tersebut sebagian dikendalikan oleh gen-gen bukan-aditif. Nilai estimasi KG bagi sifat indeks panen sebesar $6.60 \%$ dengan kriteria agak rendah. Dalam penelitianya pada kedelai, Srivastava and Jain (1994) mendapatkan hasil yang sama, yaitu heritabilitas dalam arti sempit dan kemajuan genetik yang rendah bagi sifat indeks panen karena peranan tindak gen bukan aditif. 
Harvest stage and soybean seed quality 
Genotip-genotip mempunyai variasi yang rendah hingga agak rendah bagi sifat waktu berbunga, panjang akar, waktu panen, berat biji per tanaman dan berat 100 biji dengan nilai KVG masing-masing 4.07; 7.81; 3.62; 7.83 dan 5.94\% (Tabel 1). Oleh sebab itu genotip-genotip yang digunakan menunjukkan penampilan yang lebih kurang sama bagi kelima sifat tersebut. Namun demikian, kelima sifat ini menunjukkan heritabilitas dalam arti luas dan arti sempit yang tinggi masingmasing $71,76,88,78,91 \%$ untuk heritabilitas dalam arti luas dan 95.86; 93.97; 87.53; 68.89; $84.37 \%$ untuk heritabilitas dalam arti sempit. Nilai heritabilitas dalam arti luas yang tinggi bagi sifatsifat ini bermakna bahwa sifat-sifat tersebut lebih banyak dikendalikan oleh faktor genetik. Heritabilitas dalam arti sempit yang lebih tinggi dibandingkan dengan heritabilitas dalam arti luas bagi sifat waktu berbunga dan panjang akar menunjukkan bahwa kedua sifat tersebut sepenuh nya dikendalikan oleh tindak gen aditif. Hal ini diperjelas dengan nilai nisbah potensi kedua sifat ini yang bernilai nol dan sumbangan varians aditif terhadap varians genetik mencapai $100 \%$. Jain (1982) melaporkan bahwa sifat-sifat yang dikendalikan sepenuhnya oleh tindak gen aditif menunjukkan heritabilitas dalam arti sempit yang lebih tinggi dibandingkan dengan heritabilitas dalam arti luasnya. Untuk sifat waktu panen, berat biji per tanaman dan berat 100 biji sumbangan varians aditif terhadap varians genetik masingmasing sebesar 94.54; 89.41 dan 87.78\%. Oleh sebab itu ketiga sifat ini sebagian besar dikendalikan oleh tindak gen aditif. Ketiga sifat ini menunjukkan nilai nisbah potensi masing-masing $0.14 ; 0.37$ dan -0.38 . Oleh sebab itu gen dominan yang mengendalikan sifat waktu panen dan berat biji per tanaman adalah gen dominan sebagian positif, sedangkan sifat berat 100 biji dikendalikan oleh gen dominan sebagian negatif. Nilai estimasi KG bagi kelima sifat ini dengan kriteria agak tinggi hingga tinggi masing-masing $7.07 ; 13.98 ; 6.98$; 14.30 dan $11.69 \%$. Hasil ini sesuai dengan pendapat Burton (1952) yang mengatakan bahwa heritabilitas dan kemajuan genetik yang tinggi menunjukkan terdapat peranan yang besar tindak gen aditif dan epistasis (aditif $\mathrm{x}$ aditif dan aditif $\mathrm{x}$ dominan) yang mengendalikan sifat-sifat tersebut.

Genotip-genotip menunjukkan variasi agak tinggi hingga tinggi bagi sifat jumlah buku subur, jumlah cabang produktif, berat kering tanaman, luas daun, berat kering akar dan nisbah berat kering akar : berat kering tanaman dengan nilai $\mathrm{KVG}$ masing-masing $14.78 ; 16.63 ; 12.04 ; 13.67 ; 17.88$ dan $13.93 \%$ (Tabel 1). Hal ini bermakna bahwa genotip-genotip ini menunjukkan penampilan yang berbeda satu dengan yang lain bagi keenam sifat tersebut. Variasi yang tinggi sangat penting dalam seleksi karena efektifitas seleksi tergantung pada besarnya variasi genetik (Hallauer, 1987). Sifatsifat ini menunjukkan heritabilitas dalam arti luas yang tinggi masing-masing 76, 70, 82, 79, 86 dan $95 \%$. Oleh sebab itu sifat-sifat ini lebih banyak dikendalikan oleh faktor genetik dibandingkan dengan faktor lingkungan. Namun demikian, sifatsifat tersebut menunjukkan heritabilitas dalam arti sempit yang rendah hingga agak rendah masingmasing $42.88 ; 26.59 ; 5.58 ; 32.30 ; 42.29$ dan $0.20 \%$. Hasil ini juga sesuai dengan analisis tindak gen dimana sumbangan varians aditif terhadap varians genetik untuk keenam sifat tersebut masingmasing hanya $48.02 ; 30.22 ; 5.91 ; 34.48 ; 44.44$ dan $22.22 \%$. Dengan demikian keenam sifat tersebut lebih banyak dikendalikan oleh tindak gen bukan aditif, yaitu dominan dan epistasis (aditif $\mathrm{x}$ dominan dan dominan $\mathrm{x}$ dominan). Nilai nisbah potensi keenam sifat tersebut masing-masing adalah 1.19; 1.49; 2.37; 0.33; 0.71 dan 0.27. Dengan demikian tindak gen dominan yang mengendalikan sifat jumlah buku subur, jumlah cabang produktif dan berat kering tanaman adalah gen overdominan positif, sedangkan gen dominan yang mengendali kan sifat luas daun, berat kering akar dan nisbah berat kering akar : berat kering tanaman adalah gen dominan sebagian positif. Nilai estimasi KG keenam sifat ini adalah tinggi masing-masing $26.48 ; 28.71 ; 22.41 ; 25.01 ; 34.23$ dan $27.97 \%$ (Tabel 1). Oleh karena tindak gen dominan sebagian positif dan overdominan berperanan dalam menentukan penampilan sifat-sifat tersebut, maka kemajuan genetik yang tinggi dapat dicapai melalui pemanfaatan heterosis.

Genotip-genotip menunjukkan variasi agak tinggi bagi sifat jumlah polong isi dengan $\mathrm{KVG}$ 
9.22\%. Sifat ini menunjukkan heritabilitas dalam arti luas dan arti sempit yang tinggi masing-masing sebesar 76 dan $65.70 \%$. Sumbangan varians aditif terhadap varians genetik sebesar $74.70 \%$ sehingga peranan tindak gen aditif sangat penting dalam mengendalikan sifat ini. Nilai nisbah potensi untuk sifat ini sebesar 0.50. Dengan demikian tindak gen dominan yang mengendalikan sifat ini adalah gen dominan sebagian positif. Nilai estimasi KG sifat ini $15.77 \%$ dalam kategori tinggi (Tabel 1) disebab kan oleh variasi genetik dan heritabilitas sifat ini yang cukup tinggi.

\section{KESIMPULAN}

Sifat tinggi tanaman dan indeks panen menunjukkan variasi genetik yang rendah, heritabilitas dalam arti luas yang tinggi dan heritabilitas dalam arti sempit yang rendah. Sifat tinggi tanaman dikendalikan oleh tindak gen aditif dan bukan aditif (dominan sebagian positif). Sifat indeks panen dikendalikan oleh tindak gen dominan lengkap negatif dan epistasis. Estimasi kemajuan genetik untuk sifat tinggi tanaman adalah tinggi, sedangkan estimasi kemajuan genetik sifat indeks panen adalah rendah.

Sifat waktu berbunga, panjang akar, waktu panen, berat biji per tanaman dan berat 100 biji menujukkan variasi genetik yang rendah, heritabilitas dalam arti luas dan sempit yang tinggi. Sifat waktu berbunga dan panjang akar sepenuhnya dikendalikan oleh tindak gen aditif. Sifat waktu panen, berat biji per tanaman dan berat 100 biji sebagian besar dikendalikan oleh tindak gen aditif dan gen dominan sebagian positif untuk sifat waktu panen dan berat biji per tanaman, sedangkan gen dominan yang mengendalikan sifat berat 100 biji adalah gen dominan sebagian negatif. Estimasi kemajuan genetik kelima sifat ini adalah tinggi.

Sifat jumlah buku subur, jumlah cabang produktif, berat kering tanaman, luas daun, berat kering akar dan nisbah berat kering akar : berat kering tanaman menunjukkan variasi genetik yang tinggi, heritabilitas dalam arti luas yang tinggi, heritabilitas dalam arti sempit yang rendah dan lebih banyak dikendalikan oleh tindak gen bukan aditif.
Sifat jumlah buku subur, jumlah cabang produktif dan berat kering tanaman dikendalikan oleh tindak gen overdominan positif dan epistasis. Sifat luas daun, berat kering akar dan nisbah berat kering akar : berat kering tanaman dikendalikan oleh tindak gen dominan sebagian positif dan epistasis. Kemajuan genetik yang tinggi pada sifat-sifat ini dapat dicapai melalui pemanfaatan heterosis.

Sifat jumlah polong isi menunjukkan variasi genetik yang tinggi, heritabilitas dalam arti luas dan arti sempit yang tinggi. Sifat ini sebagian besar dikendalikan oleh tindak gen aditif, gen dominan sebagian positif dan epistasis. Estimasi kemajuan genetik sifat ini adalah tinggi.

\section{DAFTAR PUSTAKA}

Borojevic, S. 1990. Principles and methods of plant breeding. Elseivier, Amsterdam.

Brewbaker, J.L. 1964. Agricultural genetics. Prentice-Hall Inc, Englewood Cliffs New York.

Burton, G.W.1952. Quantitative inheritance in pearl millet (Pennisetum glaucum). Agron. J.43 : 409-457.

Cahaner, A. and J. Hillel. 1980. Estimating heritability and genetic correlation between traits from generation $\mathrm{F}_{2}$ and $\mathrm{F}_{3}$ of selffertilizing species : a comparison of three methods. Theor. Appl. Genet. 58: 33-38

Crowder, L.V. 1981. Genetika tumbuhan (terjemahan L. Kusdiarti dan Soetarso). Gadjah Mada University Press, Yogyakarta.

Dudley, J.W. and R. H. Moll. 1969. Interpretation and uses of estimates of heritability and genetic variances in plant breeding. Crop Sci. $9: 257-262$

Falconer, D.S. 1989. Introduction to quantitative genetics. John Wiley and Sons Inc, New York.

Falconer, D.S. and T.F.C. Mackay. 1996. Introduction to quantitative genetics. Longman, Harlow

Fehr, W.R. 1987. Principles of cultivar development, theory and technique. Macmillan Publishing Company, New York.

Haeruman, M., A. Baihaki, G. Satari, T. Danakusuma, dan A. H. Permadi. 1990. 
Variasi genetik sifat-sifat tanaman bawang putih di Indonesia. Zuriat 1(1) : 32-36

Hallauer, A.R. 1987. Maize. In Fehr, W.R. (ed.). Principles of cultivar development Crop species. 2 : 249-294. Machmillan Publishing Company, A Division of Macmillan Inc, New York.

Hayward, G. 1990. Applied Genetics. Macmillan Education Ltd, Hampshire.

Jain, J.P. 1982. Statistical techniques in quantitative genetics. Tata Mc Graw-Hill Publishing Company Ltd, New Delhi.

Karuniawan, A., R. Setiamihardja, N. Hermiati dan A. Baihaki. 1991. Nilai heritabilitas lima komponen hasil kedelai dengan tiga metode pendugaan. Zuriat 2(2) : 64-68

Knight, R. 1979. Practical in statistics and quantitative genetic. In R. Knight, (ed). A course manual in plant breeding, p. 213-225. Australian Vice-Chancelors Committee.

Mak, C. 1986. Genetic studies and breeding of soybean. In A.H. Zakri and B.S. Jalani (eds). Soybean improvement in Malaysia. $p$ 19-79. UKM, Bangi.

Poehlman, J.M. 1979. Breeding field crop. AVI Publishing Company Inc, Westport-
Connecticut.

Rachmadi, M., N. Hermiati, A. Baihaki dan R. Setiamihardja. 1990. Variasi genetik dan heritabilitas komponen hasil dan hasil galur harapan kedelai. Zuriat 1(1) : 48-51

Singh, J.N. and B. R. Murty. 1982. Diallel analysis in tetralocular Brassica campestris. Indian. J. Genet. 42 : 257-260

Singh, R.K. and B.D. Caudhari. 1979. Biometrical methos in quantitative genetics analysis. Kalyani Publisher, Ludhiana, New Delhi.

Srivastava, A.N. and J.K. Jain. 1994. Variability and coheritability estimates for physiological and economic attributes in soybean. Indian J. Genet. 54 (2) : 179-183

Sujiprihati, S. M. Syukur dan R. Yunianti. 2005. Pendugaan ragam genetik dan heritabilitas beberapa karakter vegetatif dan hasil jagung manis. J. Agrotropika 10 (2) : 75-78

Yap, T.C., M. Chai and M.S. Saad. 1990. Pembiakbakaan tumbuhan. Dewan Bahasa dan Pustaka-Kementeriaan Pendidikan Malaysia, Kuala Lumpur.

Zen, S. 1995. Heritabilitas, korelasi genotipik dan fenotipik karakter padi gogo. Zuriat 6(1): 2532. 